\title{
PENINGKATAN ANGKA PEROKSIDA PADA MINYAK GORENG CURAH TERHADAP PENGGORENGAN BERULANG TEMPE
}

\author{
Rosmayani Hasibuan \\ Jurusan Analis Kesehatan Politeknik Kesehatan Kemenkes Medan
}

\begin{abstract}
Abstrak
Minyak goreng merupakan kebutuhan pokok yang digunakan dalam memasak sebagai media penghantar panas pada proses menumis maupun menggoreng yang akan memberikan citarasa yang lebih lezat, dan aroma serta penampilan makanan yang lebih menarik. Kerusakan minyak goreng ditandai dengan terjadinya perubahan bau atau flavor dalam minyak yaitu berupa bau tengik yang disebabkan oleh karena penggunanan minyak goreng secara berulang-ulang dan juga karena penyimpanan minyak goreng yang tidak baik sehingga menyebabkan minyak terhidrolisis dan teroksidasi. Tujuan penelitian adalah untuk mengetahui peningkatan angka peroksida pada minyak goreng curah terhadap penggorengan berulang tempeyangdilaksanakan di Laboratorium Politeknik Kesehatan Jurusan Analis Kesehatan dengan menggunakan metode titrasi Iodometri pada bulanApril - Juni 2012. Dari hasil penelitian terhadap 5 (lima) sampel minyak goreng curah sebelum penggorengan, terdapat 1 (satu) sampel yang memenuhi syarat mutu minyak goreng sesuai dengan SNI-3741-1995 yaitu sampel A sebesar 1,99 meq/kg, sedangkan 4 (empat) sampel yang lainnya ( B, C, D dan E) tidak memenuhi syarat mutu minyak goreng, yaitu sebesar 2,19-2,80 meq/kg. Setelah dilakukan penggorengan berulang sebanyak 5 (lima) kali, terjadi peningkatan angka peroksida yaitupada penggorengan I sebesar 1,19-1,28 meq/kg, penggorengan II sebesar 2,30-2,62 meq/kg, penggorengan III sebesar 2,96-3,15 meq/kg,penggorengan IV sebesar3,67-4,00 meq/kg dan penggorengan $\mathrm{V}$ sebesar 5,44-5,76 $\mathrm{meq} / \mathrm{kg}$.
\end{abstract}

Kata Kunci : Minyakgorengcurah,Bilangan peroksida, Iodometri

\section{PENDAHULUAN}

\section{Latar Belakang}

Salah satu kebutuhan dasar manusia yang penting adalah pangan.Dalam kehidupan sehari-hari kita melakukan aktivitas.Untuk melakukan itu kita memerlukan energi, seperti halnya karbohidrat, protein, dan lemak merupakan sumber energi bagi tubuh (Budiyanto, 2004).Selain itu lemak dan minyak juga merupakan sumber energi yang lebih efektif dibandingkan karbohidrat dan protein.Satu gram lemak dan minyakdapat menghasilkan 9 kkal, sedangkan karbohidrat dan protein hanya menghasilkan 4 kkal setiap gram (Winarno, 2005).Kebutuhan lemak tidak dinyatakan secara mutlak. Badan WHO (1990) menganjurkan konsumsi lemak sebanyak 15 - $30 \%$ kebutuhan energi totaldianggap baik untuk kesehatan. Jumlah ini memenuhi kebutuhan akan asam lemak esensial dan untuk membantu penyerapan vitamin larut - lemak.

Salah satu bahan makanan yang dapat memenuhi kebutuhan lemak manusia adalah minyak goreng.Minyak goreng adalah minyak nabati yang telah dimurnikan dan dapat digunakan sebagai bahan pangan.Minyak goreng merupakan salah satu dari sembilan bahan pokok yang dikonsumsi oleh seluruh lapisan masyarakat. Konsumsi minyak goreng biasanya digunakan sebagai media untuk menggoreng bahan pangan, menambah cita rasa, ataupun shortening yang membentuk tekstur pada pembuatan roti (Dwi Oktaviani, 2009).

Minyak goreng yang baik mempunyai sifat tahan panas, stabil pada cahaya matahari, tidak merusak flavour hasil gorengan, sedikit gum, menghasilkan produk dengan tekstur dan rasa yang bagus, asapnya sedikit setelah digunakan berulangulang, serta menghasilkan warna keemasan pada produk (SusinggihWijana, dkk, 2005).

Kerusakan minyak atau lemak juga diakibatkan pemanasan pada suhu tinggi $\left(200-250^{\circ} \mathrm{C}\right)$, yang terjadi selama proses penggorengan, hal ini akan mempengaruhi kualitas minyak dan nilai gizi dari bahan pangan yang digoreng (Sunita, Almatsier. 2004).

Penggorengan merupakan proses thermal yang menghasilkan karakteristik makanan gorengan dengan warna coklat keemasan, tekstur krispi penampakan dan flafour yang diinginkan sehingga makanan gorengan sangat popular (Boskou, et al , 2006). Selama penggorengan akan terjadi oksidasi dari dekomposisi minyak yang dipengaruhi oleh bahan pangan dan kondisi penggorengan ( Chatzilazaro, et al, 2006 ).

Produksi komponen komponen minyak selama penggorengan dapat memberikan efek yang dapat merugikan kesehatan. Salah satu fenomena yang dihadapi dlm proses penggorengan adalah menurunnya kualitas minyak setelah digunakan secara berulang pada suhu yang 
relative tinggi $\left(160-180^{\circ} \mathrm{C}\right)$. Paparan oksigen dan suhu tinggi pada minyak goreng akan memicu terjadinya oksidasi..(T. Panangan, Almunady. 2010)

Penggunaan minyak jelantah yang berkelanjutan oleh manusia dapat menyebabkan berbagai macam penyakit diantaranya penyakit kanker, dapat mengurangi kecerdasan generasi berikutnya, dan pengendapan lemak dan pembuluh darah. Selain itu, selama penggorengan akan terbentuk senyawa akrolein yang bersifat racun dan menimbulkan gatal pada tenggorokan (Wildan, Farihan. 2002.).

Saat ini masih banyak ditemukan minyak goreng tidak bermerek tanpa kemasan di pasaran yang dijual secara eceran per-kilogram dengan harga murah atau lebih dikenal dengan minyak goreng curah, seperti yang terlihat di Pasar Aksara Medan. Minyak ini disimpan dalam wadah yang cukup besar seperti : jerigen, drum, atau wadah lain sejenisnya dan dalam keadaan terbuka sebelum disalurkan kepada masyarakat. Masyarakat selama ini masih banyak yang menggunakan minyak goreng curah yang didistribusikan dalam bentuk tanpa kemasan yang berarti bahwa minyak goreng curah sebelum digunakan banyak terpapar oksigen.Namun kondisi ini sering kali menjadi sebuah dilema, disatu sisi masyarakat kita cenderung masih berorientasi pada nilai ekonomis ketimbang nilai kesehatannya.

Selain daripada itu masyarakat Indonesia suka menggunakan minyak goreng secara berulang bahkan warna minyak gorengpun menjadi berubah coklat sampai kehitaman, hal ini sangat memungkinkan terjadinya oksidasi yang lebih tinggi (Aminah dan Isworo 2009 ). Salah satu makanan yang sering dikonsumsi masyarakat baik untuk di restoran maupun rumah tangga yang penggorengannya selalu dilakukan berulang adalah tempe. Penggorengan berulang paling sering dilakukan pada waktu menggoreng bahan tersebut, dimana terkadang sampai warna tempetersebut tidak bersih lagi seperti pertama kali digoreng.

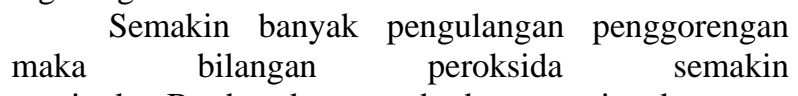
meningkat.Berdasarkan standard mutu minyak goreng di Indonesia yang diatur dalam SNI-3741-1995 bahwa standard bilangan peroksida untuk minyak goreng adalah maksimal $2 \mathrm{meq} / \mathrm{Kg}$ (SusinggihWijana, dkk, 2005).

Mengingat banyaknya minyak goreng curah yang digunakan masyarakat, maka perlu dilakukan penelitian tentangangka peroksida dalam minyak goreng yang telah digunakan berulang.

\section{Perumusan Masalah}

Berdasarkan latar belakang yang telah diuraikan maka penulis merumuskan masalah yaituseberapa besar peningkatanangka peroksida dalam minyak goreng yang telah digunakan berulang.

\section{Tujuan Penelitian}

\section{Tujuan umum}

Untuk mengetahuipeningkatan angka peroksidapada minyak goreng curah sesudah penggorengan berulang terhadap tempe.

\section{Tujuan khusus}

1.Untuk menentukan angka peroksida dalam minyak goreng curah sebelum penggorengan.

2. Untuk menentukan angka peroksida dalam minyak goreng curah sesudah penggorengan berulang.

\section{Manfaat Penelitian}

1.Sebagai bahan pengetahuan kepada masyarakat agar lebih teliti dalam memilih minyak goreng yang akan dikonsumsi setiap hari dan tidak membiasakan penggunaan minyak goreng secara berulang.

2.Sebagai bahan informasi untuk penelitian yang sama dengan bahan makanan yang berbeda

\section{METODOLOGI PENELITIAN}

\section{Lokasi dan Waktu Penelitian}

Penelitian dilakukan di Laboratorium Kimia Politeknik Kesehatan Kementerian Kesehatan, Jurusan Analis.pada bulanApril - Juni 2012.

\section{Metode Penelitian}

Penelitian ini dilakukan dengan metode survey yang bersifat deskriptif dengan tujuan untuk mengetahui peningkatan angka peroksida pada minyak goreng curah yang digunakan berulang sebanyak 5 (lima) kali.

\section{Populasi, sampel, dan Bahan makanan. Populasi Penelitian}

Populasi penelitian adalah seluruh minyak goreng curahyang diperjualbelikandari10 pedagang di Pasar Aksara Medan.

\section{Sampel Penelitian dan bahan.}

Sampel pada penelitian yaitu 5 jenis minyak goreng curah dari 10pedagang. Sampel diambil dari ciri ciri minyak goreng yaitu tidak jernih, sedikit tengik dan wadah yang terbuka.Bahan makanan yang digoreng adalah tempe.

\section{Metode pemeriksaan}

Metode pemeriksaan dilakukan dengan metode Iodometri dengan cara titrasi.

Alat

Alat - alat yang digunakan dalam penelitian ini adalah, Labu erlenmeyer bertutup, Labu ukur, Gelas ukur, Gelas kimia, Pipet berskala, Buret, Klem dan statif, Neraca analitik, Batang pengaduk, Penangas air

\section{Reagensia}

Reagensia yang digunakan dalam penelitianini adalah,Natrium thiosulfat $0,1 \mathrm{~N}$, Natrium thiosulfat $0,01 \mathrm{~N}$, 
KI 20 \%, Larutan $\mathrm{KIO}_{3}$ 0,1 N, Larutan $\mathrm{KIO}_{3}$ 0,01 N, HCL $4 \mathrm{~N}$, Larutan amilum $1 \%$

\section{Prosedur Kerja}

\section{Standarisasi larutan $\mathrm{Na}_{2} \mathrm{~S}_{2} \mathrm{O}_{3} \mathbf{0 , 0 1} \mathbf{N}$}

Dipipet 10,00 $\mathrm{ml} \mathrm{KIO}_{3}$ 0,01 $\mathrm{N}$ lalu dimasukkan ke dalam labu erlemeyer $250 \mathrm{ml}$. Kemudian ditambah 10 ml KI $20 \%$ dan 10 ml HCL 4 N masukkan ke dalam labu erlenmeyer di atas, kocok dan biarkan beberapa menit sambil ditutup dengan plastik. Lalu diencerkan dengan aquades sebanyak $10 \mathrm{ml}$. Dititrasi dengan $\mathrm{Na}_{2} \mathrm{~S}_{2} \mathrm{O}_{3} 0,01 \mathrm{~N}$ hingga warna kuning muda Kemudian ditambah $1 \mathrm{ml}$ amilum $1 \%$ dan titrasi kembali dengan $\mathrm{Na}_{2} \mathrm{~S}_{2} \mathrm{O}_{3}$ 0,01 N hingga warna biru tepat hilang.

\section{Penetapan Blanko}

Kedalam labu erlenmeyer $250 \mathrm{ml}$, dimasukkan aquadest sebanyak 5,00 ml. lalu ditambah $30 \mathrm{ml}$ campuran larutan dari $20 \mathrm{ml}$ asam asetat glasial, $25 \mathrm{ml}$ methanol 95\%, dan $55 \mathrm{ml}$ kloroform. Kemudian Ditambah satu gram kristal Kalium Iodida dan disimpan di tempat gelap selama 30 menit. Lalu ditambahkan 50,00 ml air suling bebas $\mathrm{CO}_{2}$, Dititrasi dengan larutan standard natrium thiosulfat dengan larutan kanji (amylum) sebagai indikator

\section{Penentuan Angka Peroksida Sebelum Penggorengan.}

Ditimbang ke dalam labu erlenmeyer $250 \mathrm{ml}$, sebanyak $\pm 5,0$ gram minyak goreng curah yang belum digunakan untuk menggoreng, lalu ditambah $30 \mathrm{ml}$ campuran larutan dari $20 \mathrm{ml}$ asam asetat glasial, $25 \mathrm{ml}$ methanol 95 \%, dan 55 ml kloroform. Kemudian Ditambah satu gram kristal Kalium Iodida dan disimpan di tempat gelap selama 30 menit. Lalu ditambahkan 50,00 ml air suling bebas $\mathrm{CO}_{2}$, Dititrasi dengan larutan standard natrium thiosulfat dengan larutan kanji (amylum) sebagai indikator.
Penentuan Angka Peroksida Sesudah Penggorengan.

Ditimbang ke dalam labu erlenmeyer $250 \mathrm{ml}$, sebanyak \pm 5,0 gram minyak goreng curah yang sudah digunakan untuk menggoreng tempe ( 1 s/d 5 kali penggorengan ) lalu ditambah $30 \mathrm{ml}$ campuran larutan dari $20 \mathrm{ml}$ asam asetat glasial, $25 \mathrm{ml}$ methanol $95 \%$, dan $55 \mathrm{ml}$ kloroform. Kemudian Ditambah satu gram kristal Kalium Iodida dan disimpan di tempat gelap selama 30 menit. Lalu ditambahkan 50,00 ml air suling bebas $\mathrm{CO}_{2}$, Dititrasi dengan larutan standard natrium thiosulfat dengan larutan kanji (amylum) sebagai indikator

\section{Perhitungan}

Angkaperoksida $($ meq $/ \mathrm{kg})=\frac{(V 1-V o) x T x 1000}{m}$ Keterangan :

$V_{\mathrm{o}} \quad$ adalah nilai numerik volume dari larutan natrium thiosulfat untuk blanko, dinyatakan dalam ml

$V_{1} \quad$ adalah numerik volume dari larutan natrium thiosulfat untuk contoh, dinyatakan dalam ml

$T$ adalah normalitas larutan standard natrium thiosulfat yang digunakan dinyatakan dalam $\mathrm{meq} / \mathrm{ml}$

m berat sampel (gram )

\section{HASIL DANPEMBAHASAN}

\section{Data Hasil Penelitian}

Dari hasil penelitian yang dilakukan terhadap minyak goreng curah di laboratorium Politeknik Kesehatan Jurusan Analis Kesehatan Medan, maka diperoleh hasil sebagai berikut

Tabel Data Penimbangan Sampel dan Hasil Titrasi.

\begin{tabular}{|c|c|c|c|c|c|c|c|c|c|c|c|c|c|}
\hline \multirow[t]{2}{*}{ NO } & \multirow{2}{*}{$\begin{array}{c}\text { Kode } \\
\text { Sampel }\end{array}$} & \multicolumn{6}{|c|}{ Berat Sampel Rata rata (gr) } & \multicolumn{6}{|c|}{$\begin{array}{l}\text { Volume Titrasi Rata rata } \mathrm{Na}_{2} \mathrm{~S}_{2} \mathrm{O}_{3} \\
(\mathrm{ml})\end{array}$} \\
\hline & & SP & P1 & P2 & P3 & P4 & P5 & SP & P1 & P2 & P3 & P4 & P5 \\
\hline 1 & $\mathrm{~A}$ & 5,0222 & 5,0488 & 5,0069 & 5,0085 & 5,0108 & 5,0618 & 1,50 & 2,15 & 3,30 & 4,85 & 6,75 & 9,70 \\
\hline 2 & $\mathrm{~B}$ & 5,0002 & 5,0235 & 5,0124 & 5,0339 & 5,0091 & 5,0186 & 1,75 & 2,40 & 3,60 & 5,20 & 7,00 & 10,00 \\
\hline 3 & $\mathrm{C}$ & 5,0130 & 5,0421 & 5,0096 & 5,0050 & 5,0115 & 5,0516 & 1,90 & 2,50 & 3,80 & 5,35 & 7,20 & 10,00 \\
\hline 4 & $\mathrm{D}$ & 5,0005 & 5,0240 & 5,0130 & 5,0350 & 5,0102 & 5,0192 & 1,60 & 2,20 & 3,40 & 4,90 & 7,00 & 9,90 \\
\hline 5 & $\mathrm{E}$ & 5,0325 & 5,0502 & 5,0125 & 5,0138 & 5,0256 & 5,0745 & 1,80 & 2,40 & 3,60 & 5,20 & 7,05 & 9,95 \\
\hline 6 & $\mathrm{~F}$ & & & & & & & & 0,50 & & & & \\
\hline
\end{tabular}

Keterangan Sampel : $\quad \begin{array}{ll}\mathrm{A}-\mathrm{E} & =\text { Sampel Minyak Goreng Curah } \\ \mathrm{F} & =\text { Blanko } \\ \mathrm{SP} & =\text { Sebelum Penggorengan }\end{array}$

P1- P5 = 1s/d $5 \times$ penggorengan 
Data Hasil Bilangan Peroksida

Tabel.Angka Peroksida Sebelum dan Sesudah Penggorengan Berulang.

\begin{tabular}{|c|c|c|c|c|c|c|c|}
\hline \multirow{2}{*}{ NO } & \multirow{6}{*}{ Kode Sampel } & \multicolumn{7}{|c|}{ Hasil (meq/kg) } \\
\cline { 3 - 8 } & & SP & P1 & P2 & P3 & P4 & P5 \\
& & & & & & & \\
\hline 1 & A & 1,99 & 3,30 & 5,60 & 8,68 & 12,47 & 18,17 \\
\hline 2 & B & 2,50 & 3,78 & 6,18 & 9,33 & 13,33 & 18,92 \\
\hline 3 & C & 2,80 & 3,96 & 6,58 & 9,69 & 13,36 & 18,80 \\
\hline 4 & D & 2,19 & 3,38 & 5,78 & 8,74 & 12,97 & 18,73 \\
\hline 5 & E & 2,53 & 3,76 & 6,18 & 9,33 & 13,03 & 18,62 \\
\hline
\end{tabular}

Tabel.Peningkatan Angka Peroksida Pada Penggorengan Berulang

\begin{tabular}{|c|c|c|c|c|c|c|}
\hline \multirow{2}{*}{ NO } & \multirow{2}{*}{ Kode Sampel } & \multicolumn{5}{|c|}{ Peningkatan Angka Peroksida (meq/kg) } \\
\cline { 3 - 7 } & & P1 & P2 & P3 & P4 & P5 \\
\hline & & & & & & 5,70 \\
\hline 1 & A & 1,31 & 2,30 & 3,08 & 3,79 & 5,60 \\
\hline 3 & B & 1,28 & 2,40 & 3,15 & 4,00 & 5,44 \\
\hline 4 & C & 1,16 & 2,62 & 3,11 & 3,67 & 5,76 \\
\hline 5 & D & 1,19 & 2,40 & 2,96 & 4,23 & 5,59 \\
\hline
\end{tabular}

\section{PEMBAHASAN}

Menurut SNI-3741-1995 tentang syarat minyak goreng untuk Angka peroksida maksimum adalah 2 $\mathrm{meq} / \mathrm{kg}$.

Dari hasil penelitian yang dilakukan terhadap 5 (lima) sampel minyak goreng curah yang diperjualbelikan di Pasar Aksara Medan, terdapat hanya 1 (satu) sampel minyak goreng sebelum penggorengan yang hampir memenuhi syarat mutu minyak goreng yaitu sampel A yaitu sebesar 1,99 meq/kg sedangkan sampel yang lainnya tidak memenuhi syarat mutu minyak goreng, yaitu sampel A, C, D, dan E, lebih dari $2 \mathrm{meq} / \mathrm{kg}$. Setelah dilakukan 5 (lima) kali pengggorengan, terdapat penigkatan yang signifikan pada tiap kali dilakukan penggorengan berulang.

Hal ini disebabkan karena pemanasan pada suhu tinggi yang terjadi selama proses penggorengan, terutama pada penggorengan yang dilakukan berulangulang dan ini akan mempengaruhi kualitas minyak dan nilai gizi dari bahan pangan yang digoreng. Faktor yang mempercepat kerusakan minyak juga adalah adanya cahaya, oksigen, air, dan panas.Penyimpanan yang salah dalam jangka waktu tertentu dapat juga menyebabkan pecahnya ikatan trigliserida pada minyak lalu membentuk gliserol, asam lemak bebas, dan menyebabkan pembentukan bilangan peroksida pada minyak. (SusinggihWijana, dkk, 2005).

Penyimpanan minyak goreng curah di pasaran tidak terlalu memperhatikan nilai kesehatannya. Salah satu contoh penyimpanan minyak goreng yang salah yang sering kita lihat di pasar adalah, penyimpanaan pada wadah dalam kondisi terbuka, di mana bila minyak goreng dibiarkan terlalu lama kontak dengan udara dan juga cahaya akan menyebabkan minyak goreng teroksidasi dan terhidrolisis. Pada proses hidrolisis, lemak dan minyak akan diubah menjadi asam lemak bebas dan gliserol. Reaksi hidrolisis dapat mengakibatkan kerusakan lemak atau minyak karena terdapat sejumlah air di dalamnya, sehingga menimbulkan bau tengik. Hasil penelitian Alyas et al. (2006) menunjukkan peningkatan bilanganperoksida yang signifikan dengan meningkatnya suhu dan waktupenggorengan. Aidos et al. (2001) juga melaporkanbahwa peningkatan bilangan peroksida signifikan dengan peningkatan suhupenyimpanan. Hasil tersebut menunjukkan adanya efek sinergis suhu yangtinggi dengan waktu yang lama terhadap bilangan peroksida.

\section{SIMPULAN DAN SARAN}

\section{Simpulan}

Dari 5 (lima) sampel sebelum penggorengan diperoleh hasil bilangan peroksidanya 1,99-2,80meq/kg.Dari 5 (lima) sampel minyak goreng curah yang dianalisa, terdapat 1 (satu) sampel minyak goreng sebelum penggorengan yang masih memenuhi syarat mutu minyak goreng yaitu sampel A, sebesar 1,99 meq/kg sedangkan sampel yang lainnya tidak memenuhi syarat mutu minyak goreng yaitu maksimum sebesar $2 \mathrm{meq} / \mathrm{kg}$. Setelah dilakukan penggorengan berulang sebanyak lima kali, terjadi peningkatan angka peroksida pada penggorengan I adalah sebesar 1,19-1,28 meq/kg, penggorengan II sebesar 2,30-2,62 meq/kg penggorengan III sebesar 2,96-3,15 meq/kg, penggorengan IV sebesar 3,67-4,00 meq/kg dan penggorengan $V$ sebesar 5,44-5,76 meq/kg.

\section{Saran}

Adapun saran yang dapat disampaikan penulis adalah :

1. Kepada produsen minyak goreng curah supaya lebih memperhatikan penyimpanan minyak goreng 
agar tidak terjadi kerusakan kualitas minyak goreng yang akan didistribusikan kepada masyarakat, misalnya penyimpanan pada wadah yang tertutup dan terbuat dari bahan aluminium atau stainless dan menghindari kontaminasi dengan udara, air, dan juga matahari supaya tidak terjadi hidrolisis dan oksidasi pada minyak.

2. Dianjurkan kepada masyarakat untuk tidak menggunakan minyak goreng secara berulang, karena pemakaian minyak goreng yang berulang menyebabkan kerusakan pada minyak goreng itu sendiri, di mana hal ini akan mempengaruhi kualitas minyak goreng dan nilai gizi dari bahan pangan yang digoreng.

3. Kepada peneliti selanjutnya agar dapat meneliti tentang peningkatan angka peroksida terhadap bahan makanan yang lain.

\section{DAFTAR PUSTAKA}

Aidos, I., Padt, A.F.D.,Remko, B.M., and Luten, JB., (2001). Upgrading of Maatjesherring by-products: production of crude fish oil. Journal Agriculture and FoodChemistry Vol.49 No. 8:3697-3704.

Alyas, S.A., Abdullah, A., Idris, N.A. 2006. Change of Carotene Content DuringHeating of Red Palm Olein. Journal of Oil Research (Special Issue-April 2009),p.99-120

Aminah, S., Iswara T.J. 2009.Praktek penggorengan dan mutu minyak goring sisa pada rumah tangga Rt 05 Rw III Kedungmundu Tembalang Semarang.
Budiyanto, Moch.Agus Krisno. 2004. DasarDasar Ilmu Gizi. Edisi 3 Universitas Nuhammadiyah, Malang

Dwi Oktaviani, Nita. 2009. Hubungan lamanya pemanasan dengan Kerusakan Minyak Goreng Curah Ditinjau dari Bilangan Peroksida.Jurnal Biomedika. 1 (1) : 31-35.

Ketaren,Slamat.1986. Pengantar Teknologi Minyak dan Le mak Pangan. ed1. Universitas IndonesiaJogjakarta.

Standar Nasional Indonesia 01-3741-1995. Cara Uji Minyak Goreng. DEPKES RI : Jakarta.

Sudarmadji, Slamat, dkk. 1989. Analisa Bahan Makanan dan Pertanian LibertyYogyakarta.

Sunita, Almatsier. 2004. Prinsip Dasar Ilmu Gizi.ed4. PT.Gramedia Pustaka Utama : Jakarta.

Seto, Agung. 2001.Pangan dan Gizi. IPB: Bogor.

T. Panangan, Almunady. 2010. Pengaruh Penambahan Bubuk Bawang Merah (allium ascalonicum) Terhadap Bilangan Peroksida dan Kadar Asam Lemak Bebas Minyak Goreng Curah.Jurnal Penelitian Sains. hal : 1-3.

Wildan, Farihan. 2002. Penentuan Bilangan Peroksida dalam Minyak Nabati dengan Cara Titrasi.Balai Penelitian Ternak-Ciawi. P. O. Box 221: Bogor. Hal 63-69.

Wijana, Susinggih,dkk. 2005. Mengolah Minyak Goreng B ekas.ed1 Trubus Agrisarana: Surabaya.

Winarno, F.G. 2002.Kimia Pangan dan Gizi. PT.Gramedia Pustaka Utama:Jakarta 